\title{
Bond underwriting fees and keiretsu affiliation in Japan
}

\author{
Abe de Jong, Peter Roosenboom and Willem Schramade
}

\begin{tabular}{|l|l|}
\hline \multicolumn{2}{|l|}{ ERIM REPORT SERIES RESEARCH IN MANAGEMENT } \\
\hline ERIM Report Series reference number & ERS-2005-038-F\&A \\
\hline Publication & June 2005 \\
\hline Number of pages & 37 \\
\hline Persistent paper URL & \\
\hline Email address corresponding author & wschramade @ rsm.nl \\
\hline Address & Erasmus Research Institute of Management (ERIM) \\
& RSM Erasmus University / Erasmus School of Economics \\
& Erasmus Universiteit Rotterdam \\
& P.O.Box 1738 \\
& 3000 DR Rotterdam, The Netherlands \\
& Phone: $\quad+31104081182$ \\
& Fax: $\quad+31104089640$ \\
& Email: info @erim.eur.nl \\
& Internet: $\quad$ www.erim.eur.nl \\
\hline
\end{tabular}

Bibliographic data and classifications of all the ERIM reports are also available on the ERIM website: www.erim.eur.nl 


\section{ERASMUS RESEARCH INSTITUTE OF MANAGEMENT}

REPORT SERIES

\section{RESEARCH IN MANAGEMENT}

\begin{tabular}{|c|c|}
\hline \multicolumn{2}{|c|}{ ABSTRACT AND KEYWORDS } \\
\hline Abstract & $\begin{array}{l}\text { We examine fees on bonds issued by Japanese corporations during the } 1994-2002 \text { period. We } \\
\text { relate fees to firms' membership of bank-led (financial) keiretsu. For the full sample of firms, we } \\
\text { establish a positive relation between fees and risk factors. Over time, we find that fees have } \\
\text { increased for those firms that are related to financial keiretsu, even after controlling for risk } \\
\text { factors. But during the same period, fees have fallen for firms not belonging to keiretsu. It seems } \\
\text { that, against the background of bond market deregulation and weaker banks, keiretsu } \\
\text { membership has become a burden rather than an advantage. }\end{array}$ \\
\hline Free Keywords & Fees, Bonds, Keiretsu, Corporate Groups, Banks \\
\hline Availability & $\begin{array}{l}\text { The ERIM Report Series is distributed through the following platforms: } \\
\text { Academic Repository at Erasmus University (DEAR), DEAR ERIM Series Portal } \\
\text { Social Science Research Network (SSRN), SSRN ERIM Series Webpage } \\
\text { Research Papers in Economics (REPEC), REPEC ERIM Series Webpage }\end{array}$ \\
\hline Classifications & $\begin{array}{l}\text { The electronic versions of the papers in the ERIM report Series contain bibliographic metadata } \\
\text { by the following classification systems: } \\
\text { Library of Congress Classification, (LCC) LCC Webpage } \\
\text { Journal of Economic Literature, (JEL), JEL Webpage } \\
\text { ACM Computing Classification System CCS Webpage } \\
\text { Inspec Classification scheme (ICS), ICS Webpage }\end{array}$ \\
\hline
\end{tabular}




\title{
Bond underwriting fees and keiretsu affiliation in Japan
}

\author{
Abe de Jong, Peter Roosenboom, Willem Schramade \\ Department of Financial Management \\ Rotterdam School of Management \\ Erasmus University Rotterdam
}

\begin{abstract}
We examine fees on bonds issued by Japanese corporations during the 1994-2002 period. We relate fees to firms' membership of bank-led (financial) keiretsu. For the full sample of firms, we establish a positive relation between fees and risk factors. Over time, we find that fees have increased for those firms that are related to financial keiretsu, even after controlling for risk factors. But during the same period, fees have fallen for firms not belonging to keiretsu. It seems that, against the background of bond market deregulation and weaker banks, keiretsu membership has become a burden rather than an advantage.
\end{abstract}

JEL classifications: G20, G21, G24, G30

Keywords: fees, bonds, keiretsu, corporate groups, banks

Correspondence to: Willem Schramade, Rotterdam School of Management, Erasmus University Rotterdam, Department of Financial Management, P.O. Box 1738, 3000 DR, Rotterdam, The Netherlands, wschramade@ $\mathrm{rsm} . n 1$. We thank Marc Deloof, Mathijs van Dijk, Mark Flannery, Marieke van der Poel, Yishay Yafeh, and seminar participants at the Aarhus School of Business and Ghent University for their comments. Of course, all errors remain ours. 


\title{
Bond underwriting fees and keiretsu affiliation in Japan
}

\author{
Abstract \\ We examine fees on bonds issued by Japanese corporations during the 1994-2002 \\ period. We relate fees to firms' membership of bank-led (financial) keiretsu. For \\ the full sample of firms, we establish a positive relation between fees and risk \\ factors. Over time, we find that fees have increased for those firms that are related \\ to financial keiretsu, even after controlling for risk factors. But during the same \\ period, fees have fallen for firms not belonging to keiretsu. It seems that, against \\ the background of bond market deregulation and weaker banks, keiretsu \\ membership has become a burden rather than an advantage.
}




\section{Introduction}

During the 1980s and 1990s Japanese corporate bond markets were increasingly deregulated, opening up the markets to both more issuers and more underwriters. Notable events were the admission of foreign and commercial banks to the bond underwriting market in 1993, and the deregulation of underwriting fees and relaxation of eligibility guidelines for issuers in 1994 . $^{1}$ As a result, there was a sharp decline in underwriting fees from $1.5 \%$ of proceeds in 1991 to $0.35-0.55 \%$ in $1995 .^{2}$ Another consequence of the reforms was increased access to public finance, which was especially useful for those firms not belonging to financial keiretsu. Until then keiretsu membership had meant better access to finance and insurance against failure (Sheard, 1989, Hoshi et al., 1991). But in the 1990s, the banks at the core of these financial keiretsu increasingly got into trouble and could no longer guarantee bail-out to its member firms.

Against the background of bond market deregulation and the weakening of the position of banks, we examine fees on bond issues by Japanese corporations during the 1994-2002 period, to investigate the effects of keiretsu affiliation. Our focus is on bonds, because they are closely linked to the bankruptcy costs that are supposed to be lower for keiretsu firms (e.g. Hoshi et al., 1990). Moreover, they were the most important source of public finance for Japanese firms in the 1990s. Over the 1993-1999 period, Japanese firms issued for Yen 70.6 trillion in bonds against Yen 15.4 trillion in equity. ${ }^{3}$ To our knowledge, the relation between fees and keiretsu affiliation has not been investigated in earlier studies.

\footnotetext{
${ }^{1}$ Financial Institution Reform Act, passed in June 1992, effective in April 1993.

${ }^{2}$ Finance and Fiscal Affairs (Kinyu Zaisei Jijyou), December 1995

${ }^{3}$ Japan Securities Dealers Association, Factbook 2003.
} 
As in previous research on fees (e.g. Kim et al., 2003), we find that fees, also referred to as spreads, increase in issue risk at the individual issue level. More importantly, we find that fees have risen over time for members of financial keiretsu, while they have fallen for nonaffiliated firms. This relation holds after controlling for risk factors. We see these rising fees as evidence that the costs of keiretsu membership have come to outweigh the benefits. Banklead corporate groups may have been an efficient solution to missing markets for public finance. But their success declined as the banks at their core suffered from the combined effects of deregulation and the 1990 burst of the financial bubble. Because banks could no longer guarantee bail-out to their member firms, the advantage of reduced bankruptcy costs diminished. Moreover, the disadvantages of being affiliated increased as the problems of keiretsu banks spilled over to affiliated firms. For example, Horiuchi and Shimizu (1998) report substantial placements of subordinated debt with affiliated firms, and Weinstein and Yafeh (1998) find higher costs of capital for keiretsu firms. Our results suggest that these spillovers also included higher fees on corporate bonds.

The next section first discusses the features of financial keiretsu, then continues with the parallel developments of financial market deregulation and the weakening of banks, and finally discusses the literature on underwriting fees. Sections 3 and 4 present data and results. Section 5 concludes.

\section{Literature and hypotheses}

We start this section with a description of financial keiretsu and their advantages and disadvantages. Subsequently, we discuss how two simultaneous developments, namely bond market deregulation and feeble banks, have weakened the keiretsu system. Finally, we will relate increased keiretsu affiliation to fees on bond issues. 


\subsection{Keiretsu}

The Japanese versions of corporate groups are called keiretsu, and they come in two types. Vertical keiretsu are centered around a manufacturing firm and have an industry focus, whereas financial or horizontal keiretsu are centered around a large bank, and are active in many industries. These financial keiretsu will be the focus of our analysis. In the remainder of the paper we refer to financial keiretsu simply as keiretsu. Banks, although not allowed to own more than $5 \%$ of shares in a firm, are the most powerful players in the keiretsu. They yield their influence through cross-shareholdings, interlocking directorships and a Presidents' council where the keiretsu's most important firms meet. Moreover, the banks use their creditor rights to take full control in distressed group firms. Keiretsu advantages and disadvantages have been very well documented in the literature.

A major advantage of the keiretsu system is its ability to solve information problems. For example, the keiretsu's main bank is argued to be both a superior monitor and a potential intervention agent (e.g., Sheard, 1989). Aoki (1990) emphasizes that the very threat of a bank takeover also plays an important monitoring role. In a similar vein, Berglöf and Perotti (1994) claim that the cross-holdings of debt and equity within keiretsu act as a coalition-enforced threat of removal from control. Moreover, Hoshi et al. (1990) argue that keiretsu reduce bankruptcy costs by easier renegotiation and better access to capital. They find that after the onset of distress, affiliated firms invest more and sell more than non-affiliated firms. Main banks implicitly guarantee the loans made to their affiliated firms by other banks and voluntarily take more than their share of the losses in case of distress (Aoki, 1988, and Hoshi et al., 1990). Furthermore, since the main bank implicitly guarantees to bail out distressed members, affiliation can be seen as a form of insurance against bankruptcy (Sheard, 1989). 
A flaw of the system is the potential for rent-seeking behavior, consistent with Rajan's (1992) hold-up model. Rent-seeking includes demanding too high interest rates and distorting investment decisions toward projects with low risk, high collateral and high leverage. Morck and Nakamura (1999), and Morck et al. (2000) find evidence of such rent-seeking behavior by banks. The distortion of investment decisions is also noted by Weinstein and Yafeh (1995) who find that keiretsu firms are both larger and more levered. Under bank influence, they produce more than optimal for value maximization. As a result, they are larger than their efficient size. Moreover, Weinstein and Yafeh (1998) find that affiliated firms are less profitable and have higher costs of capital. The lower profitability of keiretsu firms has also been found by Prowse (1992) and Kang and Shivdasani (1999). Nakatani (1984) argues that this lower profitability is offset by lower risk and more stable cash flows, but Beason (1998) does not find any support for this argument: although affiliated firms indeed perform worse, they do not have lower share price volatility.

Several observations indicate that the costs of keiretsu membership began to outweigh the benefits by the 1990s. First, over the past decade there has been a continuous dissolution of cross-holdings ('Cross-shareholdings decline for the $11^{\text {th }}$ straight year', NLI Research Institute, January 2002). Second, as previously mentioned, keiretsu members perform worse than non-affiliated firms. Third, as we will argue in the next subsection, since the banks are in a state of crisis themselves, they can no longer perform their intervention function properly. Fourth, as we will show in section 2.3 , bond market access has improved, thus reducing the need to be a keiretsu member to have access to public finance.

\subsection{Weaker banks}


With the burst of the stock market and real estate bubble in 1990, Japanese banks were left with a vast portfolio of non-performing corporate and property loans. Moreover, their reserves declined due to the depressed equity prices. Profits fell, the bad loans grew worse and the first banks began to fall. There had not been a single bank failure since World War II, but from late 1994 to mid 1996, eight banks failed (Financial Times, 19 July 1996). The banking crisis was highlighted in late 1997, when Japanese banks were even paying up to half a percentage point above the LIBOR, the so-called "Japanese premium". The convoy policy, in which the government ordered strong banks to help their weaker competitors, only worsened the problems (see e.g. Bremer and Pettway, 2002). In 1999 there was a wave of merger announcements among banks, most of them becoming effective in 2001. Seven out of eight core keiretsu banks were involved in mergers among themselves, leaving eight keiretsu with only four main banks ${ }^{4}$. In the meantime, the banks' problems spilled over to firms with close banking ties. For example, banks managed to substantially mitigate the shortfall in equity capital by issuing subordinated debt which was largely placed with affiliated firms (Horiuchi and Shimizu, 1998). In addition, Kang and Stulz (2000) report that exogenous shocks to banks during Basle negotiations resulted in negative spillovers to bank clients, as they find that Japanese firms with more bank loans in 1989 performed worse in the 1990-1993 period. Thus, the close banking ties inherent to keiretsu affiliation have become much less appealing. An interesting example is the Fuyo keiretsu, where bad performance and a weak financial core resulted in the failure or sale of several important group members in late 1997 and early 1998 ,

\footnotetext{
${ }^{4}$ In 1999 Fuji Bank (Fuyo), Dai-Ichi Kangyo Bank (DKB), and the Industrial Bank of Japan (IBJ) announced to form the Mizuho financial group. In the same year, Sakura Bank (Mitsui) and Sumitomo Bank decided to become the Sumitomo Mitsui Banking Corporation, while Sanwa Bank and Tokai Bank teamed up to be United Financial of Japan (UFJ). As a result, now only four main banks remain for eight keiretsu. This may even be reduced to three banks as the troubled UFJ is about to be taken over by Mitsubishi Tokyo Financial.
} 
including Showa Line, Nihon Cement, Toa Steel, and the broker Yamaichi ('Inside the Fuyo keiretsu', Financial Times, 28 October 1998).

\subsection{Bond market development}

The Japanese bond markets were heavily regulated until the end of the 1970s, with limited access for both potential underwriters and firms wanting to issue bonds. For issuers, very strict eligibility prevailed, which ensured that only three firms could issue unsecured bonds in 1979. In addition, until 1993 there were caps to the amount that could be issued. Moreover, issuance required the involvement of a bond issuance committee ('kisaikai') dominated by banks, which resulted in a strong bargaining position for banks and high issuance costs, as the principal management bank charged fees that totaled 2-3\% of the bond's principal (Yasuda, 2001). However, in 1988 the kisaikai was abolished. As to the eligibility guidelines, they were gradually loosened so that by 1989 they were met by over 300 firms (Hoshi et al., 1993) and by approximately 500 firms in April 1993. Later, the lowest credit rating of companies eligible to issue unsecured bonds was lowered from A to BBB and the number of firms eligible to issue uncollateralized bonds increased to approximately 800 (Financial Times, 1 June 1995). Eventually, speculative grade firms were allowed to issue as well. Hoshi et al., 1993 show that this resulted in a shift from bank to public debt. Many firms that used to issue in the Eurobond market and many more firms that previously did not issue at all, began to issue in the domestic bond market during the late eighties and nineties. The amount of corporate bonds outstanding almost doubled from 1993 to 2002 (Japan Securities Dealers Association, Fact Book 2003), in spite of the deterioration in the financial condition of both issuers and banks by 1996 (Schena, 2002). As access to finance was one of the main advantages of the keiretsu system, the increased issuer access is likely to have made keiretsu affiliation less attractive. 
Entry into the market for underwriter services was limited too. During the 1980s and the early 1990s, the Japanese Big Four investment banks (Nomura, Yamaichi, Nikko, and Daiwa) dominated the market with over 95\% market share ${ }^{5}$. But in April 1993 the Financial System Reform Law became effective which gradually allowed foreign and commercial banks to underwrite bond issues. The result was that Japanese commercial banks took a large part of the bond underwriting market: the market share in corporate bond underwriting of the Big Four fell from 89\% in 1994 to 62\% in 1996 (The Nikkei Weekly, 14 April 1997). Nomura eventually recovered, but Nikko was sold to Citigroup and Yamaichi even failed in November 1997. Another result was that fees paid to underwriters fell from $1.5 \%$ in 1991 to $0.35-0.55 \%$ in $1995 .{ }^{6}$ In the next section we will discuss the determinants of fees and the relation with keiretsu affiliation.

\subsection{Fees}

When investment banks underwrite securities, they charge substantial fees to the issuer. Fees are usually defined as a percentage of proceeds. On a $\$ 1$ billion bond issue, underwriters can easily charge $1 \%$ or $\$ 10$ million in fees. In spite of their economic significance, fees have received limited attention in the literature. Fees partly reflect the amount of effort investment bankers put into the underwriting process. In addition, fees are a compensation for the risk the underwriter is exposed to. That is, the underwriter's position can be described as a short position in a put option (Smith, 1977). The risk exists both in terms of direct cash flow consequences and in terms of potential loss of reputation and future market share.

Accordingly, Kim et al. (2003) find issue and firm characteristics, such as leverage, rating and maturity to be the main explanatory variables for fees on US bond issues.

\footnotetext{
${ }^{5}$ SDC league tables

${ }^{6}$ Finance and Fiscal Affairs (Kinyu Zaisei Jijyou), December 1995
} 
In other studies, fees have mainly been related to competition among underwriters, with underwriting fees found to decrease as competition increases. For example, Carow (1999) finds for various US securities markets that fees fall as innovative securities become mainstream. And for corporate debt markets specifically, fees have diminished with commercial bank entry in the US (Gande, et al., 1999) and with the Euro introduction for Eurobond markets (Santos and Tsatsaronis, 2003). When competition is frustrated by collusion of underwriters, fees remain high, as found for the US equity IPO market (Chen and Ritter, 2000).

Fees also depend on underwriter characteristics. Chemmanur and Fulghieri (1994) show that high reputation investment banks can charge higher fees than their less reputable competitors. But empirical evidence is mixed for US and Eurobond corporate debt markets. Esho et al. (2002) confirm Chemmanur and Fulghieri's (1994) predictions, whereas Santos and Tsatsaronis (2003) and Livingston and Miller (2000) find that high reputation investment banks charge lower fees. In addition to underwriter reputation, the type of underwriter may also matter. In Puri's (1999) model, commercial banks, as lenders to firms, are better certifiers than investment banks. Therefore, commercial banks should charge higher fees than investment banks. However, for a sample of US corporate debt issues, Roten and Mullineaux (2002) find that commercial banks charge lower fees than investment banks. This may be explained by the fact that in their sample commercial banks have only just entered the market.

Since keiretsu affiliation seems to have become disadvantageous, this might be reflected in affiliated firms paying higher fees. This result should hold even after controlling for 
underwriter identity, issue risk and firm risk. In the next section we will discuss how we obtain our data and how we try to establish the link between keiretsu affiliation and fees.

\section{Data and descriptive statistics}

\subsection{Data}

From the SDC New Issues Database Data we select all domestic non-convertible fixed-rate corporate bond issues in the April 1994-2002 period, which are 3248 issues in total. We start in April 1994 because before that time SDC does not report information on fees on Japanese domestic bond issues. We focus on domestic issues because foreign issues are not comparable in terms of fees, due to different market conditions such as regulation and investment banking competition. The same applies to bonds with option-like features. Furthermore, we exclude financial firms as they are in the same industry as the underwriters and could potentially underwrite themselves. After exclusion of financials, 2924 issues are left. Fees data are available for 2899 of these issues. Other issue data, such as coupon, maturity, and syndicate composition are also taken from the SDC New Issues Database. Additional issuer data, e.g. sales and capital structure ratios are obtained from Worldscope and Thomson One. For 2519 issues we have all variables to be included in our regressions.

For identifying keiretsu firms, Brown's (formerly Dodwell Marketing Consultants) 'Industrial Groupings in Japan' is the most widely used source ${ }^{7}$. It is used by for example Kang and Shivdasani (1999) and Weinstein and Yafeh (1998). We employ both the 1995 and 2001 editions of Industrial Groupings in Japan, roughly corresponding with the beginning and end

\footnotetext{
${ }^{7}$ Other sources are Keizai Chosa Kyokai's 'Keiretsu no Kenkyu', and Toyo Keizai's 'Kigyyo Keiretsu Soran', but these have not been published recently. According to Yafeh (2002), the cessation of their publication is another indication of the keiretsu's demise.
} 
of our sample period, to establish whether issuers belonged to a financial keiretsu. In the next section, we discuss descriptive statistics on keiretsu firms versus non-affiliated firms, fees, and on other issue and firm characteristics.

\subsection{Descriptive statistics}

\subsubsection{Keiretsu}

Table 1 shows the eight financial keiretsu and their sizes, both in number of firms and in sales.

\section{$<$ Please insert Table 1 here $>$}

As the sales figures and number of affiliated firms show, the keiretsu are vast groups. They even grew in number of firms during the 1990s, which suggests an increasing economic significance. But that impression is only superficial and due to a trend of both starting new ventures and spinning off parts of firms that remain within the keiretsu. The sales figures show a different picture. Due to the previously mentioned disappointing operating performance, sales declined for all groups, in spite of the new ventures.

The 189 keiretsu firms in our sample issued $\$ 149$ billion in straight corporate bonds in the Japanese domestic market, which is $36 \%$ of the total issue amount in the sample. Keiretsu firms account for $47 \%$ of the 392 issuing firms and for just over half of the issues, which means that, on average, they issued slightly more bonds per firm than non-affiliated firms. An additional $13 \%$ of the firms belonged to a vertical keiretsu, making the percentage of firms belonging to either type of keiretsu $60 \%$. This is more than the about 40 to $50 \%$ of listed manufacturing firms as reported by Weinstein and Yafeh (1995), but less than the $84 \%$ 
reported by Nakatani (1984). Our classification is corroborated by Morck, Nakamura and Shivdasani's (2000) more recent sample, where $51 \%$ of firms belong to a financial keiretsu, which is close to the $47 \%$ we find.

Keiretsu affiliation is relatively stable among our sample firms. Out of the 189 issuers that were members in at least one period, 175 were so in both periods. Eight firms are not listed as members in the 1995 edition of Industrial Groupings in Japan, but do appear in the 2001 edition. Three of them issued both before and during membership. Six firms appeared in the 1995 edition of Industrial Groupings in Japan, but do not return in the 2001 edition. None of these firms issued after 1998. For the other 378 firms in the sample (both members and nonmembers) affiliation did not change. This membership stability seems inconsistent with the dissolution of cross-holdings that has been going on over the past decade ${ }^{8}$. Note however, that bond issuers are generally large firms, even compared to other keiretsu firms. Average keiretsu firm sales were around \$1,5 billion in 1999 (Industrial Groupings in Japan, 2001), versus $\$ 13,8$ billion for the average affiliated firm that issued in 1999. Given their importance to the keiretsu, it is hardly surprising that membership among large firms is very stable. In fact, we find that the vast majority (79\% of issues) of keiretsu firms are classified 4-star by Industrial Groupings in Japan. A mere $11 \%$ of keiretsu firms have a 4-star classification, but 4-star firms account for $79 \%$ of all issues by keiretsu firms. This 4-star classification means that group members have a majority of the voting rights in the firm, and that the firm is a member of the presidents' council. Only the largest firms in the keiretsu are typically admitted to the presidents' council.

\subsubsection{Fees}

\footnotetext{
${ }^{8}$ NLI Research Institute, 2002, Cross-shareholdings decline for the $11^{\text {th }}$ straight year
} 
Mean fees over the sample period are stable at just over $0.4 \%$ of proceeds, with the median at exactly $0.4 \%$, and a standard deviation of $0.0085 \%$. Given the sample mean issue size of $\$ 165$ million, the mean dollar amount of fees is 680,000 . The $0.4 \%$ average is lower than previous studies find for Eurobond and US corporate debt markets (e.g. Kim et al., 2003 and Esho et $a l ., 2002)$. The stability at just over $0.4 \%$ is misleading however, because when comparing fees for issues by affiliated with those by non-affiliated firms, a very different picture emerges, as Figure 1 shows.

$<$ Please insert Figure 1 here $>$

During the first half of the sample period keiretsu firms enjoyed a slight discount in fees, but after 1998, this discount turned into a premium. Median fees for both affiliated and nonaffiliated fees are at the same level as mean fees.

\subsubsection{Issue characteristics}

Means of fees and of other issue characteristics are given in Table 2, for affiliated and nonaffiliated firm separately, and for each year of the sample period.

$<$ Please insert Table 2 here $>$

Panel A shows the number of issues and the amount issued by affiliated and non-affiliated firms respectively. Issues by non-affiliated firm were typically larger, with a mean (median) value of \$214 million (\$151 million). The average mean (median) issue size of affiliated firms equals $\$ 117$ million (\$86 million). The total sample average is at \$163 million. Affiliates and non-affiliates placed approximately the same amount of issues, with affiliated firm doing slightly more issues up until 1999, and non-affiliated firms slightly more issues in the last few 
years. In general their numbers went up and down within the same proportions for most of the sample period, although the fall in issues by affiliated firms after 1998 is somewhat sharper than the fall in issues by non-affiliated firms.

Similar to Figure 1, Panel B of Table 2 distinguishes fees for issues of both types of firms. Initially, fees are lower for affiliated firms, but then they become increasingly higher than fees for non-affiliated firms. The coupons they pay follow a similar, though weaker pattern, also with an initial advantage turning into a later disadvantage. Only the principal amount as a percentage of total assets lacks a clear pattern. For the other variables, the differences between affiliated and non-affiliated firms are stable over the sample period. That is, affiliated firms place smaller issues, their bonds have shorter maturities, and they hire less managers in their underwriting syndicate over the whole sample period. It seems both types of firms do different kinds of issues, but these differences existed over the whole period, so they do not provide an explanation for the change from a discount to a premium.

\subsubsection{Firm characteristics}

Next, we investigate firm characteristics. When looking at the industry distribution, we find that keiretsu firms are more often active in materials and consumer products, whereas nonaffiliated firms dominate in the retail and energy sectors. Table 3 gives means of (previous year's) financial statement items for those firms that issued in that particular year, again split by both types of firms

$<$ Please insert Table 3 here $>$ 
As to size, affiliated firms are smaller in terms of total assets for each sample year, but in terms of sales the picture is not very clear, with large swings in average sales. Affiliated firms have less fixed assets as a percentage of total assets, which is probably due to more nonaffiliated firms being in capital intensive industries, which also explains their consistently higher mean total assets. Weinstein and Yafeh (1995) find that keiretsu firms are both larger and more levered. However, they compare affiliated and non-affiliated firms among listed manufacturing firms, not specifically among bond issuers, which are likely to be larger and more levered than the average listed firm. Therefore, in our sample affiliated and nonaffiliated firms are more probably more comparable in terms of size and leverage. For most of the sample period both types of firms have similar debt ratios at around $65 \%$. However, at similar total debt ratios, affiliated firms have lower long-term debt ratios than non-affiliated firms, indicating that affiliated firms have more short-term debt, which might reflect more bank debt or more trade credit from other affiliated firms.

As found in previous research (e.g., Prowse, 1992, Weinstein and Yafeh, 1998, and Kang and Shivdasani, 1999), affiliated firms are less profitable than non-affiliated firms. We find significantly lower ROA and ROE, and also lower market-to-book ratios for most sample years. At the same time, keiretsu firms have higher earnings volatility during the whole sample period, which seems inconsistent with the idea of more stable cash flows (e.g. Nakatani, 1984, Khanna and Yafeh, 2005). But it is consistent with Beason (1998), who finds that the lower profitability of keiretsu firms is not offset by lower stock volatility. In spite of lower profitability, keiretsu firms in our sample are more liquid than non-affiliated firms, with significantly higher mean current ratios (and quick ratios) for each sample year. Overall levels of current ratios are low, with those of non-affiliated firms even on average being below one. This is in line with Hoshi, et al.'s $(1989,1991)$ findings for the 1980s that non-affiliated firms 
are more liquidity constrained. Morck and Nakamura (1999) argue that affiliated firms have higher liquidity so as to avoid disciplining from banks.

\section{Methodology}

To establish the relationship between keiretsu, risk, and fees, we run OLS regressions on fees. The basic model takes the following form:

$$
\begin{aligned}
& \text { FEES }_{i}=\alpha+\beta_{1} L O G\left(\text { PRINC }_{i}\right)+\beta_{2} L O G\left(\text { SALES }_{i}\right)+\beta_{3} \text { COUP }_{i}+\beta_{4} M_{A} T_{i}+\beta_{5} D R_{i} \\
& +\beta_{6} \text { SDEBTA5 }_{i}+\beta_{7} F A_{i}+\beta_{8} C R_{i}+\beta_{9} R O A_{i}+\beta_{10} M B_{i}+\beta_{11} B K_{i}+\beta_{12} B 4_{i}+\beta_{13} F K_{i}+ \\
& \beta_{14} F K_{i} * Y 95_{i}+. .+\beta_{21} F K_{i} * Y 02_{i}+\beta_{22} Y 95_{i}+. .+\beta_{29} Y 02+\beta_{30} I N D 1_{i}+. .+\beta_{39} I N D 10_{i}
\end{aligned}
$$

Underwriting fees are defined as a percentage of issue size, as in for example Gande et al. (1999) and Kim et al. (2003). Table 4 gives an overview of the independent variables to be used in the regressions, and the predicted signs of their coefficients.

\section{$<$ Please insert Table 4 here $>$}

The affiliated dummy (FK) equals one if the firm belongs to a financial keiretsu according to the Industrial Groupings in Japan classification. This dummy is used to establish the relation between keiretsu and fees. We interact FK with the year dummies to account for changes in the influence of affiliation over time. Most other variables are meant to establish the link between fees and risk. Consistent with Altinkilic and Hansen (2000), we take both the size of the issue, LOG(PRINC), and the size of the issuing firm, LOG(SALES), into account. At a fixed firm size, larger issues are riskier than smaller ones. At a fixed issue size, issues by large firms are less risky than those by smaller firms. Therefore, we expect fees to relate positively to issue size (measured as the log of the principal amount) and negatively to firm size (as measured by the $\log$ of sales or the log of total assets). An obvious proxy for risk would be the bond's credit rating. We do not use it here because in our sample only $14 \%$ of the issues are 
rated by either S\&P or Moody's, and we do not have the ratings by Japanese agencies such as Mikuni, JCR, JBRI or NIS. We believe this is not problematic given that issue and firm characteristics are good predictors of rating in our sample ${ }^{9}$. Issue characteristics to be used as regressors on fees include issue size, but also the bond's coupon (COUP), its maturity (MAT), and the type of underwriter (B4, BK). MAT, or Maturity is the number of years between the issue date and the planned redemption of the issue. Coupon (COUP) is the promised annual payment to be made to the bondholders, as a percentage of the issue size. Both are expected to be positively related to issue risk.

We employ two dummies to control for the type of underwriter. First, there is a dummy (B4) that equals one if the lead manager of the underwriting syndicate is one of the Big Four firms (Nomura, Yamaichi, Nikko and Daiwa). These firms have traditionally been the most reputable underwriters in Japan. Since Chemmanur and Fulghieri's (1994) model predicts that high reputation underwriters charge higher fees than their less reputable counterparts, we expect to find a positive sign for this dummy. Second, we use a dummy (BK) that equals one if the lead manager belongs to the same keiretsu as the issuer. It is difficult to attach a predicted sign to this dummy. On the one hand, a positive sign will result if keiretsu banks have a strong bargaining position via-à-vis their member firms and charge them higher fees. On the other hand, a negative sign will result if keiretsu firms benefit from their close banking relationships to obtain better deals and pay lower fees. However, such a negative sign could also result from keiretsu banks misusing their private information to underwrite less risky issues, as Hori and Osano (2002) suggest.

\footnotetext{
${ }^{9}$ To test if firm and issue characteristics are good predictors of rating, we run ordered logit regressions on the 266 rated issues in our sample. The results show that ratings increase significantly in firm size and fixed assets and decrease significantly in financial and operating risk.
} 
Firm characteristics include the aforementioned affiliated dummy and firm size, but also the firm's debt ratio (DR), variability in operating profits (SDEBTA5), fixed assets ratio (FA), current ratio $(\mathrm{CR})$, return on assets $(\mathrm{ROA})$, and market-to-book ratio $(\mathrm{MB})$. These are all measured in the year preceding the issue. Financial risk, in the form of the debt ratio, is measured as the book value of assets as a percentage of total assets. For the variability of operating profits (SDEBTA5), or operational risk, we take the 5-year standard deviation of the ratio of EBIT and total assets. For both financial and operating risk we expect a positive relation with fees. The fixed assets ratio (book value of fixed assets as a percentage of total assets), current ratio (current assets by current liabilities), and return on assets (EBIT by beginning of year total assets), are all expected to be negatively associated with risk, and thus take a negative sign. The sign of the market-to-book ratio (market value of equity by book value of equity) is not clear upfront, as it is both associated with value (low risk) and growth options (high risk).

Given the effects of competition on fees reported in several studies (e.g., Carow, 1999, Gande et al., 1999, and Santos and Tsatsaronis, 2003), and the reported fall in fees in the Japanese corporate bond market from 1991 to 1995 (Yasuda, 2001), it seems advisable to look at the change over time and include year dummies (Y95 for 1995, Y96 for 1996, etc.). As risk may also differ across industries, for example due to varying degrees of regulation, we also include industry dummies (IND1 through IND10).

\section{Results}

We run OLS regressions on fees using the independent variables discussed in section 4. To explicitly account for the possibility that the effect of keiretsu affiliation changes over time, 
we not only use year dummies, but also interact these with the affiliation dummy. Table 5 reports the results of the regressions. Model 1 is the basic model that includes all the likely explanatory variables discussed previously. Models 2 and 3 are robustness tests to model 1 , where non-significant variables are left out (model 2) or the log of sales is replaced by the log of total assets (model 3).

\section{$<$ Please insert Table 5 here $>$}

Table 5 indicates that fees indeed increase in risk, as reported by Kim et al. (2003) for the US. Fees increase in coupon, maturity, debt ratio, and earnings volatility, while they decrease in firm size (sales or total assets), liquidity, and, not significantly in a statistical sense, in fixed assets and profitability. The log of issue amount is the only variable that does not take the expected sign, nor is it statistically significant. Comparing models 2 and 3 with the basic model shows that the results are robust to model changes, also when replacing sales by total assets. Significance levels do not differ, and coefficients and $\mathrm{R}^{2}$ hardly change across the models. This is surprising since sales and total assets differ so markedly for the sample firms (see Table 3). Note however, that the economic role of size is not very substantial. The -0.005 coefficient of log sales implies that even the largest firm ( $\$ 200$ billion in sales) enjoys merely a $0.02 \%$ discount (5\% of average fees) vis à vis the smallest firm ( $\$ 120$ million in sales). The same discount results for firms that have a 1.3 percentage point (or 1.6 standard deviation) lower coupon than the sample mean coupon. Most other variables are in the same range of limited economic significance.

Much more significant in an economic sense, are the interaction terms of keiretsu affiliation with the year dummies. They show that keiretsu firms pay a premium over non-affiliated 
firms growing from $0.04 \%$ of proceeds ( $10 \%$ of average fees) in 1999 to $0.15 \%$ of proceeds (35\% of average fees) in 2002. In 1998 the premium is already visible, but is statistically not significant. Apparently this effect grows stronger over the sample period as the consequences of the banking crisis become clear.

The table also shows that Big Four investment bankers charge slightly higher fees, but in neither a statistically nor economically significant way. We also find that they typically underwrite larger issues, by larger firms with lower debt ratios and more fixed assets (not reported in tables). This is consistent with the model by Chemmanur and Fulghieri (1994) and with empirical findings by Esho et al. (2002) for US firms in the Eurobond market. There is a 0.015 percentage point ( $4 \%$ of average fees) discount for keiretsu firms that hire an underwriter from their own keiretsu. Potentially, this could be due to bankers giving discounts to their keiretsu peers, or to banks using private information to select the better issues. The latter explanation would be consistent with the suggestion by Hori and Osano (2002) that banks misuse their private information for their self-interest at the expense of other banks in bond underwriting. Upon closer inspection, we find that in close to half of the issues by keiretsu firms, they hire a bank from their own keiretsu as their lead manager. The firms that do so are much smaller (average sales significantly smaller at the 5\% level and median sales at the $10 \%$ level) than those that do not, which suggests they might be more likely to be subjected to bank hold-up. Moreover, these firms are more profitable than keiretsu firms that do not hire their keiretsu bank as underwriter (average ROA significantly larger at the $10 \%$ level, median ROA larger at the 5\% level), and have a higher standard deviation of profitability (significant at the $1 \%$ level), suggesting there might indeed be some selection by banks going on. 
As Table 5 shows that affiliated firms pay increasingly higher fees over the years, keiretsu firms could be subject to a different regime than affiliated firms. To test this, we run regressions on fees for affiliated and non-affiliated firms separately. Of course, the interaction terms of affiliation dummies with year dummies now disappear, and instead year dummies are reported independently. Table 6 shows the results of these regressions.

\section{$<$ Please insert Table 6 here $>$}

Table 6 yields results similar to Table 5 in that it shows again that fees increase in issue and firm risk. Not all the issue and firm characteristics that proxy for risk have equally strong results as in Table 5, suggesting that both types of firms are indeed subject to different dynamics. Still, most significant variables have the same sign as in the regressions of Table 5. The signs for the sizes of issue and issuer do differ however, due to the problem noted by Altinkilic and Hansen (2000) that larger issues are usually done by larger firms. Another deviation from Table 5 is the market-to-book ratio, which takes a significantly positive sign for non-affiliated firms, and a significantly negative sign for keiretsu firms. Note however, that non-affiliated firms generally have higher market-to-book ratios than affiliated ones. For non-affiliated firms, overvaluation may thus be an issue, whereas a lack of growth options may be more of a concern with respect to keiretsu firms. More importantly, Table 6 confirms that the fee differentials from Figure 1 also hold after controlling for risk, and are even reinforced compared to Table 5. All year dummies in the affiliated regression have a positive sign, while all year dummies in the non-affiliated regression have a negative sign. Surprisingly, the coefficients are significant in 15 out of 16 cases. Thus, fees for issues by affiliated firms keep rising during the sample period, while those for issues by non-affiliated firms keep falling. As Figure 1 showed earlier, nominal fees on affiliated issues rose from 
$0.400 \%$ in 1994 to $0.525 \%$ in 2002, a rise of $0.125 \%$ ( $31 \%$ of 1994 fees). But from Table 6 can be seen that, after correcting for risk, the rise amounts to $0.159 \%$, or $40 \%$ of 1994 fees. In contrast to Table 5, Table 6 shows that a difference between both types of issuers has existed at least from the start of the sample period, and not just since 1998 or 1999, although an acceleration from then on can be discerned. This acceleration coincides with the substantial divestment of shares by keiretsu firms noted earlier. We also run regressions on fees for the 917 issues by those firms with the strongest keiretsu ties, that is, the ones with a 4-star affiliation. These regressions (not reported in the tables) are similar to the one reported in table 6 for all affiliated firms, but with even larger coefficients for the year dummies. Thus the pattern stays intact but it shows that the effect increases with the intensity of affiliation.

\section{Summary and conclusions}

Over the past two decades, Japan has witnessed deregulation, increased access to public finance, and weaker banks. These events have weakened the keiretsu. In this paper we relate underwriting fees to keiretsu affiliation, controlling for risk. As in previous US research on fees (e.g. Kim et al., 2003), we find that fees increase in issue risk at the individual issue level. Increased competition among underwriters resulted in fees remaining stable over the sample period, in spite of rising issue risk. Thus, fees relatively declined, from which independent firms benefited. Affiliated firms however, had to pay an increasing premium. We interpret this finding as an indication that keiretsu membership turned from a benefit into a disadvantage. Bank-lead corporate groups may have been an efficient solution to missing markets for public finance, but they suffered when markets were deregulated. When the real estate and stock market bubble burst, the banks ran into trouble and they could no longer guarantee bail-out to its member firms. Moreover, their problems spilled over to the firms in their keiretsu. This happened in several ways, such as the substantial placements of 
subordinated debt with affiliated firms (Horiuchi and Shimizu, 1998), and higher costs of capital (Weinstein and Yafeh, 1998). Our results show that these spillovers also included higher fees on corporate bond issues. 


\section{References}

Altinkilic, O. and R.S. Hansen, 2000, Are there economies of scale in underwriting fees? Evidence of rising external financing costs, Journal of Financial and Quantitative Analysis 13(1): 191-218.

Aoki, M., 1990, Toward an economic model of the Japanese firm, Journal of Economic Literature 28, 1-27.

Beason, D., 1998, Keiretsu affiliation and share price volatility in Japan, Pacific-Basin Finance Journal 6, 27-43.

Berglöf, E. and E. Perotti, 1994, The governance structure of the Japanese financial keiretsu, Journal of Financial Economics 36, 259-284.

Bremer, M. and R.H. Pettway, 2002, Information and the market's perceptions of Japanese Bank risk: Regulation, environment, and disclosure, Pacific-Basin Finance Journal 10, 119-139.

Carow, K.A., 1999, Evidence of early-mover advantages in underwriting spreads, Journal of Financial Services Research 15, 37-55.

Chemmanur, T.J. and P. Fulghieri, 1994, Investment bank reputation, information production, and financial intermediation, Journal of Finance 49, 57-76.

Chen, H., J.R. Ritter, 2000, The seven percent solution, Journal of Finance 55, 1105-1131.

Esho, N. and M.G. Kollo, and I.G. Sharpe, 2002, Eurobond underwriter spreads, working paper.

Gande, A., M. Puri, and A. Saunders, 1999, Bank entry, competition, and the market for corporate securities underwriting, Journal of Financial Economics 54, 165-195.

Horiuchi, A. and K. Shimizu, 1998, The deterioration of bank balance sheets in Japan: risktaking and recapitalization, Pacific-Basin Finance Journal 6, 1-26. 
Hoshi, T., A.K. Kashyap, and D.S. Scharfstein, 1989, Bank monitoring and investment: evidence from the changing structure of Japanese corporate banking relationships, working paper.

Hoshi, T., A.K. Kashyap, and D.S. Scharfstein, 1990, The role of banks in reducing the costs of financial distress in Japan, Journal of Financial Economics 27, 67-88.

Hoshi, T., A.K. Kashyap, and D.S. Scharfstein, 1991, Corporate structure, liquidity, and investment: evidence from Japanese industrial groups, Quarterly Journal of Economics $106,33-60$.

Hoshi, T., A.K. Kashyap, and D.S. Scharfstein, 1993, The choice between public and private debt: an analysis of post-regulation corporate financing in Japan, NBER working paper.

Kang, J. and A. Shivdasani, 1999, Alternative mechanisms for corporate governance in Japan: An analysis of independent and bank-affiliated firms, Pacific-Basin Finance Journal 7, $1-22$.

Kang, J. and R.M. Stulz, 2000, Do banking shocks affect borrowing performance? An analysis of the Japanese experience, Journal of Business 73, 1-23.

Khanna, T., Y. Yafeh, 2005, Business groups and risk sharing around the world, Journal of Business forthcoming.

Kim, D., D. Palia, and A. Saunders, 2003, The long-run behavior of debt and equity underwriting spreads, working paper.

Livingston, M. and R. Miller, 2000, Investment bank reputation and the underwriting of nonconvertible debt, Financial Management 29, 21-34.

Morck, R. and M. Nakamura, 1999, Banks and corporate control in Japan, Journal of Finance 54, 319-339. 
Morck, R., M. Nakamura, and A. Shivdasani, 2000, Banks, ownership structure, and firm value in Japan, Journal of Business 73, 539-567.

Nakatani, I., 1984, The economic role of financial corporate grouping, in M. Aoki, ed., The economic analysis of the Japanese firm (North-Holland, Amsterdam).

Prowse, S.D., 1992, The structure of corporate ownership in Japan, Journal of Finance 47, 1121-1140.

Puri, M., 1999, Commercial banks as underwriters: implications for the going public process, Journal of Financial Economics 54, 133-163.

Rajan, R.G., 1992, Insiders and outsiders: the choice between informed and arm's-length debt, Journal of Finance 47, 1367-1400.

Roten, I.C. and D.J. Mullineaux, 2002, Debt underwriting by commercial bank-affiliated firms and investment banks: more evidence, Journal of Banking \& Finance 26, 689718.

Santos, J.A.C. and K. Tsatsaronis, 2003, The cost of barriers to entry: evidence from the market for corporate euro bond underwriting, working paper, Federal Reserve bank of New York.

Schena, P.J., 2002, Information structures and market development: recent evidence of the certification value of ratings in pricing Japanese corporate bonds, working paper.

Sheard, P., 1989, The main bank system and corporate monitoring and control in Japan, Journal of Economic Behavior and Organization 11, 399-422.

Smith, C.W., 1977, Alternative methods for raising capital, Journal of Financial Economics 5, 237-307.

Weinstein, D.E. and Y. Yafeh, 1995, Japan's corporate groups: collusive or competitive? An empirical investigation of keiretsu behavior, Journal of Industrial Economics 43, 359376. 
Weinstein, D.E. and Y. Yafeh, 1998, On the Costs of a Bank-Centered Financial System: Evidence from the Changing Main Bank Relations in Japan, Journal of Finance 53, 635-672.

Yafeh, Y., 2002, An international perspective of Japan's corporate groups and their prospects, in M. Blomström, J. Corbett, F. Hayashi, A. Kashyap, ed.: Structural Impediments to Growth in Japan (University of Chicago Press, Chicago).

Yasuda, A., 2001, Institutions, relationships and bank competition in bond underwriting markets: an international comparative study, working paper. 
Table 1

Financial keiretsu

\begin{tabular}{|c|c|c|c|c|c|c|c|}
\hline Keiretsu & $\begin{array}{c}\text { Issue } \\
\text { amount } \\
(\$ \\
\text { billion) } \\
\end{array}$ & $\begin{array}{l}\text { Number } \\
\text { of issues }\end{array}$ & $\begin{array}{c}\text { Number } \\
\text { of firms } \\
\text { in } \\
\text { Sample }\end{array}$ & $\begin{array}{c}\text { Group } \\
\text { firms in } \\
1990^{*}\end{array}$ & $\begin{array}{c}\text { Group } \\
\text { firms in } \\
2001 *\end{array}$ & $\begin{array}{c}1992 \text { Sales } \\
\text { (Yen } \\
\text { billion)* }\end{array}$ & $\begin{array}{l}1999 \text { Sales } \\
\text { (Yen } \\
\text { billion)* }\end{array}$ \\
\hline Mitsubishi & 29,8 & 204 & 30 & 178 & 271 & 43279 & 41732 \\
\hline Mitsui & 15,5 & 161 & 28 & 140 & 207 & 30865 & 27869 \\
\hline Sumitomo & 33,0 & 275 & 31 & 143 & 248 & 45300 & 39699 \\
\hline Fuyo & 24,6 & 231 & 23 & 140 & 221 & 37677 & 29811 \\
\hline DKB & 29,1 & 211 & 36 & 114 & 208 & 48055 & 34875 \\
\hline IBJ & 1,8 & 18 & 6 & 28 & 47 & 3196 & 3076 \\
\hline Sanwa & 15,7 & 174 & 29 & 112 & 193 & 35502 & 27633 \\
\hline Tokai & 1,1 & 14 & 8 & 38 & 60 & 11583 & 6886 \\
\hline $\begin{array}{l}\text { Double } \\
\text { count }^{* *}\end{array}$ & 1,5 & 15 & 2 & 3 & 2 & & \\
\hline Sub-total & 149,1 & 1273 & 189 & 890 & 1453 & 255457 & 211581 \\
\hline Non-affiliated & 266,7 & 1246 & 203 & & & & \\
\hline Total & 415,8 & 2519 & 392 & & & & \\
\hline
\end{tabular}

*Source: industrial Groupings In Japan, 1995, 2001, Brown and Company

**Taiheiyo Cement belongs to both Mitsui and Fuyo; Mitsui OSK lines to both Mitsui and Sumitomo

The table shows the eight corporate groups as identified by Brown \& Co's (formerly Dodwell Marketing Consultants) Industrial Groupings in Japan. Issue amount refers to the total proceeds from straight corporate bond issues by the groups' firms in billions of US dollars. Number of firms in sample is the number of firms that were involved in these issues. 


\section{Figure 1. Mean fees for affiliated and non-affiliated firms' issues}

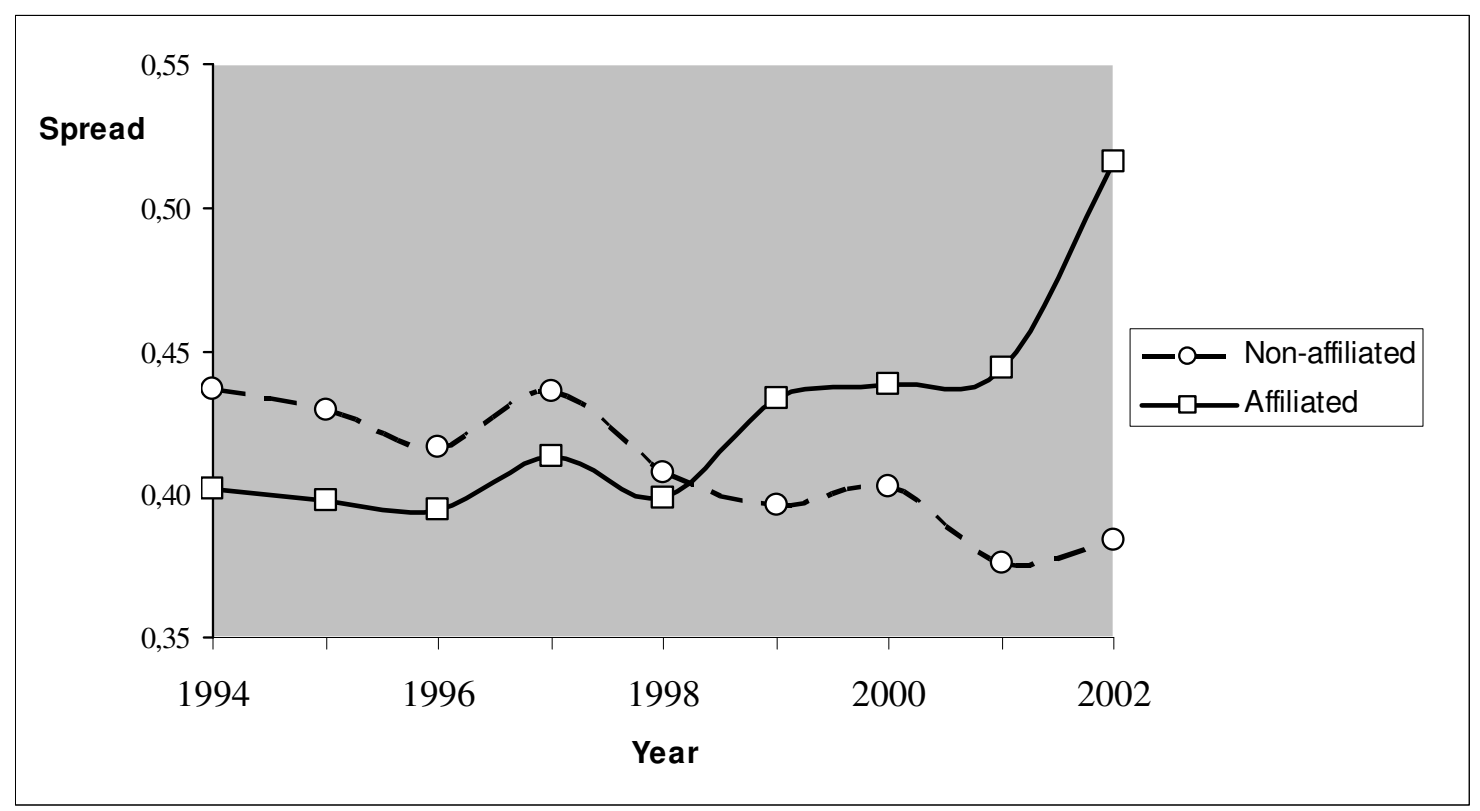

The figure shows fees on 2519 Japanese domestic bond issues included in our regressions, over the 1994-2002 period, both for firms belonging to one of the eight financial keiretsu groups identified in table 2 (affiliated firms) and for nongroup (non-affiliated) firms. Fees are gross fees paid to the underwriters as a percentage of the total proceeds of the issue. 
Table 2

Issue characteristics

Panel A: Number of issues and issue amounts

\begin{tabular}{|c|c|c|c|c|c|c|c|c|c|c|c|}
\hline & & 1994 & 1995 & 1996 & 1997 & 1998 & 1999 & 2000 & 2001 & 2002 & 1994-2002 \\
\hline \multirow[t]{3}{*}{ Number of issues } & Affiliated & 22 & 122 & 150 & 187 & 342 & 170 & 111 & 93 & 76 & 1273 \\
\hline & Non-affiliated & 46 & 86 & 136 & 159 & 306 & 131 & 130 & 114 & 138 & 1246 \\
\hline & Total & 68 & 208 & 286 & 346 & 648 & 301 & 241 & 207 & 214 & 2519 \\
\hline \multirow[t]{3}{*}{ Issue amount } & Affiliated & 6610 & 20826 & 19711 & 19582 & 33966 & 16958 & 10687 & 12769 & 8165 & 149272 \\
\hline & Non-affiliated & 15575 & 27546 & 30238 & 27895 & 49358 & 28124 & 26215 & 29877 & 31878 & 266706 \\
\hline & Total & 22185 & 48372 & 49948 & 47476 & 83325 & 45082 & 36902 & 42645 & 40043 & 415978 \\
\hline $\mathbf{N}$ & & 68 & 208 & 286 & 346 & 648 & 301 & 241 & 207 & 214 & 2519 \\
\hline
\end{tabular}

Panel B: Issue descriptives

\begin{tabular}{|c|c|c|c|c|c|c|c|c|c|c|c|}
\hline & & 1994 & 1995 & 1996 & 1997 & 1998 & 1999 & 2000 & 2001 & 2002 & $1994-2002$ \\
\hline \multirow[t]{3}{*}{ Fees } & Affiliated & 0,400 & 0,397 & 0,397 & 0,410 & 0,398 & 0,436 & 0,445 & 0,428 & 0,525 & 0,418 \\
\hline & Non-affiliated & 0,437 & 0,427 & 0,417 & 0,438 & 0,408 & 0,394 & 0,398 & 0,371 & 0,378 & 0,406 \\
\hline & Difference & $-0,038^{* * * *}$ & $-0,030 * * * *$ & $-0,021$ *** & $-0,028^{* * * *}$ & $-0,011 * * *$ & $0,042 * * * *$ & $0,047 * * *$ & $0,057 * * * *$ & 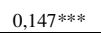 & $0,012 * * * *$ \\
\hline \multirow[t]{3}{*}{ Principal amount } & Affiliated & 300,4 & 170,7 & 131,4 & 104,7 & 99,3 & 99,8 & 96,3 & 137,3 & 107,4 & 117,3 \\
\hline & Non-affiliated & 338,6 & 320,3 & 222,3 & 175,4 & 161,3 & 214,7 & 201,7 & 262,1 & 231,0 & 214,0 \\
\hline & Difference & $-38,2$ & $-149,6 * * *$ & $-90,9 * * *$ & $-70,7 * * *$ & $-62,0^{* * * *}$ & $-114,9 * * *$ & $105,4 * * *$ & $-124,8 * * *$ & $-123,6 * * *$ & $-96,8 * * *$ \\
\hline \multirow{3}{*}{$\begin{array}{l}\text { Principal amount } \\
\text { as a percentage of } \\
\text { Total Assets }\end{array}$} & Affiliated & $2,12 \%$ & $2,40 \%$ & $2,16 \%$ & $1,70 \%$ & $1,62 \%$ & $1,36 \%$ & $2,27 \%$ & $1,13 \%$ & $1,51 \%$ & $1,77 \%$ \\
\hline & Non-affiliated & $1,36 \%$ & $3,02 \%$ & $2,47 \%$ & $2,26 \%$ & $1,75 \%$ & $1,64 \%$ & $2,02 \%$ & $1,44 \%$ & $1,10 \%$ & $1,88 \%$ \\
\hline & Difference & $0,75 \% *$ & $-0,62 \%$ & $-0,31 \%$ & $-0,56 \% * *$ & $-0,13 \%$ & $-0,28 \%$ & $0,25 \%$ & $-0,31 \%$ & $0,41 \%$ **** & $-0,11 \%$ **** \\
\hline \multirow[t]{3}{*}{ Maturity } & Affiliated & 4,80 & 6,02 & 6,16 & 7,24 & 6,21 & 6,62 & 5,91 & 5,65 & 5,52 & 6,26 \\
\hline & Non-affiliated & 7,75 & 8,18 & 7,65 & 9,50 & 8,10 & 8,16 & 7,44 & 7,28 & 7,63 & 8,03 \\
\hline & Difference & $-2,95^{* *}$ & $-2,16^{* * * *}$ & $-1,49 * * *$ & $-2,27 * * *$ & $-1,88 * * *$ & $-1,53 * * *$ & $-1,53 * * *$ & $-1,63 * * *$ & $-2,11 * * *$ & $-1,77^{* * * *}$ \\
\hline \multirow[t]{3}{*}{ Coupon } & Affiliated & 3,89 & 2,81 & 2,71 & 2,42 & 2,19 & 2,15 & 2,01 & 1,17 & 1,16 & 2,22 \\
\hline & Non-affiliated & 4,19 & 2,90 & 2,79 & 2,48 & 2,12 & 1,86 & 1,71 & 1,11 & 1,07 & 2,09 \\
\hline & Difference & $-0,29 * *$ & $-0,08$ & $-0,08$ & $-0,06$ & $0,07 *$ & $0,29 * * *$ & $0,30 * * *$ & 0,07 & 0,08 & $0,13 * * *$ \\
\hline \multirow[t]{3}{*}{$\begin{array}{l}\text { Number of } \\
\text { managers }\end{array}$} & Affiliated & 21,8 & 17,8 & 16,2 & 12,5 & 8,0 & 4,3 & 5,0 & 5,9 & 5,7 & 9,8 \\
\hline & Non-affiliated & 28,1 & 20,4 & 18,6 & 14,1 & 9,7 & 9,8 & 9,3 & 9,1 & 7,8 & 12,3 \\
\hline & Difference & $-6,3 * * *$ & $-2,6^{* * *}$ & $-2,4 * * *$ & $-1,5^{*}$ & $-1,07 * * *$ & $-5,4 * * *$ & $-4,3 * * *$ & $-3,2 * * *$ & $-2,1 * * *$ & $-2,6 * * *$ \\
\hline $\mathrm{N}$ & & 68 & 208 & 286 & 346 & 648 & 301 & 241 & 207 & 214 & 2519 \\
\hline
\end{tabular}

The table shows descriptive statistics for the 2519 issues that are included in the regressions shown in Table 5. Panel A shows the number of issues and the total amount issued in millions of US dollars, both for firms belonging to one of the eight financial keiretsu groups identified in Table 2 (affiliated firms) and for nongroup (non-affiliated) firms. Panel B reports means per year and for the whole sample period, again both for group and for nongroup (non-affiliated) firms. Differences in means for issues of both types of firms are shown too, with 1, 2 or 3 stars if they differ significantly at the $0.10,0.05$, and 0.01 levels respectively. Fees are gross fees paid to the underwriters as a percentage of the total proceeds of the issue. Principal amount equals total proceeds in millions of US dollars. Principal amount as a percentage of total assets are proceeds as a percentage of the total assets of the issuer at the end of the book year preceding the issue. Maturity signifies the number of years between the issue date and the promised redemption of the issue. Coupon is the promised annual payment to bondholders as a percentage of the bond's face value. Number of managers refers to the number of investment banks involved in the underwriting syndicate that brings the issue to the market. 
Table 3

\section{Issuing firm characteristics}

\begin{tabular}{|c|c|c|c|c|c|c|c|c|c|c|c|}
\hline & & 1994 & 1995 & 1996 & 1997 & 1998 & 1999 & 2000 & 2001 & 2002 & 1994- \\
\hline \multirow[t]{3}{*}{ Sales } & Affiliated & 38432 & 31272 & 21540 & 15066 & 14613 & 37965 & 13802 & 22654 & 11732 & 20967 \\
\hline & Non-affiliated & 17660 & 19168 & 17568 & 13741 & 18736 & 19673 & 17960 & 26048 & 22033 & 19013 \\
\hline & Difference & $20772 * *$ & $12104 *$ & 3972 & 1325 & $-4123 * *$ & $18292 * * *$ & 4158 & -3394 & 10301 **** & 1954 \\
\hline \multirow[t]{3}{*}{ Total Assets } & Affiliated & 24750 & 19833 & 16970 & 14087 & 13675 & 24583 & 11903 & 18417 & 13027 & 16515 \\
\hline & Non-affiliated & 39680 & 33141 & 28259 & 24476 & 28559 & 35910 & 32979 & 51619 & 40858 & 33438 \\
\hline & Difference & $-14930 *$ & $\frac{-}{13308 * * *}$ & $11289 * * *$ & $10388 * * *$ & $14884 * * * *$ & $11327 * * *$ & $\overline{-}^{-} 1076 * * *$ & $33202 * * *$ & $27831 * * *$ & $16923 * * *$ \\
\hline \multirow{4}{*}{ Return on Assets } & & & & & & & & & & & \\
\hline & Affiliated & 1,52 & 1,47 & 1,90 & 2,04 & 1,87 & 0,95 & 1,06 & 1,00 & 2,05 & 1,61 \\
\hline & Non-affiliated & 2,93 & 2,56 & 2,49 & 2,62 & 2,23 & 2,03 & 2,04 & 2,14 & 2,61 & 2,35 \\
\hline & Difference & $-1,41 * * *$ & $-1,09 * * *$ & $-0,58^{* * *}$ & $-0,58 * * *$ & $-0,36^{* * * *}$ & $-1,08 * * *$ & $-0,98$ *** & $-1,14 * * *$ & $-0,57$ & $-0,74 * * * *$ \\
\hline \multirow[t]{3}{*}{ Market-to-book Ratio } & Affiliated & 2,323 & 2,066 & 2,232 & 2,119 & 1,809 & 1,635 & 1,492 & 1,970 & 1,529 & 1,882 \\
\hline & Non-affiliated & 2,426 & 2,234 & 2,211 & 2,448 & 1,943 & 1,974 & 1,975 & 2,123 & 1,874 & 2,090 \\
\hline & Difference & $-0,103$ & $-0,168$ & 0,021 & $-0,329 * *$ & $-0,134 *$ & $-0,339 * * *$ & $-0,483 * * *$ & $-0,153$ & $-0,345^{* *}$ & $-0,208^{* * * *}$ \\
\hline \multirow[t]{3}{*}{$\begin{array}{l}\text { Debt as a percentage of } \\
\text { Total Assets }\end{array}$} & Affiliated & 67,89 & 64,84 & 66,29 & 64,44 & 61,28 & 73,44 & 65,70 & 66,77 & 59,39 & 65,09 \\
\hline & Non-affiliated & 72,90 & 66,13 & 64,42 & 64,37 & 60,15 & 65,42 & 65,18 & 66,95 & 63,30 & 64,09 \\
\hline & Difference & $-5,02$ & $-1,29$ & 1,87 & 0,07 & 1,13 & 8,01 *** & 0,52 & $-0,18$ & $-3,91$ & 1,00 \\
\hline \multirow[t]{3}{*}{$\begin{array}{l}\text { Long-term Debt as a } \\
\text { percentage of Total Assets }\end{array}$} & Affiliated & 53,74 & 51,05 & 52,85 & 50,03 & 46,03 & 61,84 & 53,32 & 54,23 & 46,45 & 51,41 \\
\hline & Non-affiliated & 67,64 & 58,10 & 54,22 & 54,66 & 49,97 & 59,31 & 58,03 & 61,07 & 56,34 & 55,78 \\
\hline & Difference & $-13,89^{* * * *}$ & $-7,05^{* *}$ & $-1,38$ & $-4,64 * *$ & $-3,94 * *$ & 2,53 & $-4,71$ & $-6,84 * *$ & $-9,88^{* * * *}$ & $-4,38^{* * * *}$ \\
\hline \multirow[t]{3}{*}{$\begin{array}{l}\text { Current Ratio } \\
\end{array}$} & Affiliated & 1,15 & 1,22 & 1,21 & 1,14 & 1,18 & 1,10 & 1,17 & 1,11 & 1,06 & 1,16 \\
\hline & Non-affiliated & 0,52 & 1,01 & 0,91 & 0,94 & 0,97 & 0,83 & 0,79 & 0,76 & 0,82 & 0,88 \\
\hline & Difference & $0,62^{* * * *}$ & $0,21^{\text {*** }}$ & $0,30^{* * *}$ & $0,020^{* * * *}$ & 0,21 **** & $0,27^{* * * *}$ & $0,38^{* * *}$ & $0,35^{* * * *}$ & $0,24 * * *$ & $0,28 * * *$ \\
\hline \multirow[t]{3}{*}{$\begin{array}{l}\text { Standard deviation of EBIT } \\
\text { by Total Assets }\end{array}$} & Affiliated & 0,0114 & 0,0171 & 0,0144 & 0,0109 & 0,0104 & 0,0115 & 0,0159 & 0,0170 & 0,0148 & 0,0130 \\
\hline & Non-affiliated & 0,0080 & 0,0137 & 0,0106 & 0,0092 & 0,0106 & 0,0104 & 0,0118 & 0,0138 & 0,0143 & 0,0113 \\
\hline & Difference & $0,0034 * *$ & $0,0034 * *$ & $0,0038^{* * *}$ & $0,0018^{* * *}$ & $-0,0002$ & 0,0011 & $0,0041 * * *$ & 0,0033 & 0,0005 & $0,0016 * * *$ \\
\hline \multirow[t]{3}{*}{$\begin{array}{l}\text { Fixed Assets as a percentage } \\
\text { of Total Assets }\end{array}$} & Affiliated & 0,451 & 0,431 & 0,415 & 0,382 & 0,379 & 0,361 & 0,401 & 0,365 & 0,377 & 0,389 \\
\hline & Non-affiliated & 0,796 & 0,613 & 0,537 & 0,576 & 0,537 & 0,636 & 0,654 & 0,691 & 0,614 & 0,602 \\
\hline & Difference & $-0,345^{* * * *}$ & $-0,182 * * *$ & $-0,122 * * *$ & $-0,194 * * *$ & $-0,158^{* * * *}$ & $-0,274 * * *$ & $-0,253 * * *$ & $-0,326$ *** & $-0,237$ **** & $-0,213^{* * * *}$ \\
\hline $\mathrm{N}$ & & 68 & 208 & 286 & 346 & 648 & 301 & 241 & 207 & 214 & 2519 \\
\hline
\end{tabular}

The table shows descriptive statistics of the firms that made the 2519 issues that are included in the regressions shown in Table 5. Reported are means of issuer characteristics at the end of the book year preceding the issue, for those firms that actually made an issue. Means are reported separately for firms belonging to one of the eight financial keiretsu groups identified in Table 2 (affiliated firms) and for nongroup (non-affiliated) firms. Differences in means for issues of both types of firms are also shown, with 1, 2 or 3 stars if they differ significantly at the $0.10,0.05$, and 0.01 levels respectively. Sales and total assets are in millions of US dollars. Debt values are book values. Standard deviation of EBIT by total assets is over a 5 year period. 


\section{Table 4}

\section{Variable descriptions}

\begin{tabular}{|c|c|c|c|}
\hline Variable & Label & Variable description & $\begin{array}{c}\text { Predicted relation } \\
\text { with fees }\end{array}$ \\
\hline Log of principal amount & LOG(PRINC) & Logarithm of issue proceeds in millions of dollars & + \\
\hline Log of sales & LOG(SALES) & Logarithm of the firm's previous year's sales in millions of dollars & \\
\hline Log of total assets & LOG(TA) & $\begin{array}{l}\text { Logarithm of the firm's previous year's total assets in millions of } \\
\text { dollars }\end{array}$ & - \\
\hline Coupon & COUP & $\begin{array}{l}\text { Promised annual coupon payments as a percentage of the principal } \\
\text { amount }\end{array}$ & + \\
\hline Maturity & MAT & The bond's time to maturity in years & + \\
\hline Debt ratio & DR & Book value of debt as a percentage of the book value of total assets & + \\
\hline $\begin{array}{l}\text { Standard deviation of } \\
\text { EBIT by total assets }\end{array}$ & SDEBTA5 & 5-year standard deviation of EBIT divided by total assets & + \\
\hline $\begin{array}{l}\text { Fixed assets as a } \\
\text { percentage of total assets }\end{array}$ & FA & $\begin{array}{l}\text { Book value of fixed assets as a percentage of the book value of total } \\
\text { assets }\end{array}$ & - \\
\hline Current ratio & $\mathrm{CR}$ & Current assets divided by current liabilities & - \\
\hline Return on assets & ROA & EBIT as a percentage of total assets & - \\
\hline Market-to-book & MB & Market value of equity divided by the book value of equity & $?$ \\
\hline $\begin{array}{l}\text { Lead belongs to same } \\
\text { keiretsu }\end{array}$ & $\mathrm{BK}$ & $\begin{array}{l}\text { Dummy that equals } 1 \text { if the lead manager of the underwriting } \\
\text { syndicate belongs to the same keiretsu as the issuer }\end{array}$ & $?$ \\
\hline Big Four lead & B4 & $\begin{array}{l}\text { Dummy that equals } 1 \text { if the lead manager of the underwriting } \\
\text { syndicate is a Big Four firm }\end{array}$ & + \\
\hline Affiliated & FK & $\begin{array}{l}\text { Dummy that equals } 1 \text { if the issuing firm belongs to a financial } \\
\text { keiretsu }\end{array}$ & + \\
\hline
\end{tabular}

The table shows the variables to be used in the regressions on fees and the predicted signs of their coefficients. The log of principal amount, coupon, maturity, debt ratio, standard deviation of EBIT by total assets, and the affiliated dummy are all associated with higher risk and expected to be positively related to fees. Big Four lead is a proxy for underwriter reputation, which is also associated with higher fees. The market-to-book ratio and the dummy for a lead manager belonging to the same keiretsu are variables that can go either way. The log of sales, fixed assets ratio, and current ratio are associated with lower risk, and thus have a negative sign. In addition to the variables mentioned in this table, year dummies and industry dummies will be employed too. 
Table 5

OLS Regressions on fees

\begin{tabular}{|c|c|c|c|}
\hline Model & 1 & 2 & 3 \\
\hline Constant & $\begin{array}{c}0,3531 * * * \\
(10,40)\end{array}$ & $\begin{array}{c}0,3465 * * * \\
(11,08)\end{array}$ & $\begin{array}{c}0,3507 * * * \\
(9,93)\end{array}$ \\
\hline Log of principal amount & $\begin{array}{l}-0,0008 \\
(-0,22)\end{array}$ & $\begin{array}{l}-0.0006 \\
(-0,16)\end{array}$ & $\begin{array}{l}-0,0005 \\
(-0,14)\end{array}$ \\
\hline Log of sales & $\begin{array}{c}-0,00521 * * * \\
(-3,52)\end{array}$ & $\begin{array}{c}-0,0049 * * * \\
(-3,45)\end{array}$ & \\
\hline Log of total assets & & & $\begin{array}{c}-0,0055^{* * *} \\
(-3,28)\end{array}$ \\
\hline Coupon & $\begin{array}{c}0,0150 * * * \\
(3,24)\end{array}$ & $\begin{array}{c}0,01546^{* * *} \\
(3,35)\end{array}$ & $\begin{array}{c}0,0149 \text { *** } \\
(3,17)\end{array}$ \\
\hline Maturity & $\begin{array}{c}0,0070 * * * \\
(10,81)\end{array}$ & $\begin{array}{c}0,0068 * * * \\
(10,73)\end{array}$ & $\begin{array}{c}0,0070 * * * \\
(10,69)\end{array}$ \\
\hline Debt ratio & $\begin{array}{c}0,0005^{* * *} \\
(3,87)\end{array}$ & $\begin{array}{c}0,0005^{* * * *} \\
(4,75)\end{array}$ & $\begin{array}{c}0,0005^{* * *} \\
(4,17)\end{array}$ \\
\hline $\begin{array}{c}\text { Standard deviation of EBIT } \\
\text { by total assets }\end{array}$ & $\begin{array}{c}0,6038 * * \\
(2,42)\end{array}$ & $\begin{array}{c}0,6086 * * \\
(2,42)\end{array}$ & $\begin{array}{c}0,5925 * * \\
(2,56)\end{array}$ \\
\hline $\begin{array}{c}\text { Fixed assets as a percentage } \\
\text { of total assets }\end{array}$ & $\begin{array}{l}-0,0175 \\
(-1,61)\end{array}$ & $\begin{array}{c}-0,0203^{*} \\
(-1,86)\end{array}$ & $\begin{array}{l}-0,0135 \\
(-1,26)\end{array}$ \\
\hline Current ratio & $\begin{array}{c}-0,0097 * * * \\
(-3,26)\end{array}$ & $\begin{array}{c}-0,0098 * * * \\
(-3,19)\end{array}$ & $\begin{array}{c}-0,0091 * * * \\
(3,10)\end{array}$ \\
\hline Return on assets & $\begin{array}{l}-0,00175 \\
-(1,10)\end{array}$ & & $\begin{array}{c}-0,0018 \\
(-1,14)\end{array}$ \\
\hline Market-to-book & $\begin{array}{l}-0,0011 \\
(-0,83)\end{array}$ & & $\begin{array}{l}-0,0010 \\
(-0,79)\end{array}$ \\
\hline $\begin{array}{l}\text { Lead belongs to same keiretsu } \\
\text { as the issuer }\end{array}$ & $\begin{array}{c}-0.0141 * * * \\
(-2,97)\end{array}$ & $\begin{array}{c}-0,0155^{* * *} \\
(-3,57)\end{array}$ & $\begin{array}{c}-0,0140 * * * \\
(-2,94)\end{array}$ \\
\hline Big four lead & $\begin{array}{c}0.004646 \\
(1,48)\end{array}$ & & $\begin{array}{r}0,0048 \\
(1,52)\end{array}$ \\
\hline Keiretsu affiliated & $\begin{array}{c}-0,01 \\
(-0,88)\end{array}$ & $\begin{array}{c}-0,0076 \\
(-0,67)\end{array}$ & $\begin{array}{c}-0,0108 \\
(-0,96)\end{array}$ \\
\hline $1995^{*}$ Keiretsu affiliated & $\begin{array}{l}0,0001 \\
(0,00)\end{array}$ & $\begin{array}{l}-0,0007 \\
(-0,06)\end{array}$ & $\begin{array}{c}0,0012 \\
(0,11)\end{array}$ \\
\hline $1996 *$ Keiretsu affiliated & $\begin{array}{l}-0,0029 \\
(-0,25)\end{array}$ & $\begin{array}{c}-0,0046 \\
(-0,40)\end{array}$ & $\begin{array}{l}-0,0022 \\
(-0,19)\end{array}$ \\
\hline $1997 *$ Keiretsu affiliated & $\begin{array}{l}0,0011 \\
(0,10)\end{array}$ & $\begin{array}{l}-0,0002 \\
(-0,01)\end{array}$ & $\begin{array}{l}0,002 \\
(0,18)\end{array}$ \\
\hline $1998 *$ Keiretsu affiliated & $\begin{array}{r}0,0113 \\
(1,02)\end{array}$ & $\begin{array}{l}0,0093 \\
(0,84)\end{array}$ & $\begin{array}{l}0,0123 \\
(1,12)\end{array}$ \\
\hline $1999 *$ Keiretsu affiliated & $\begin{array}{c}0,0441^{* * *} \\
(3,27)\end{array}$ & $\begin{array}{c}0,0431 * * * \\
(3,20)\end{array}$ & $\begin{array}{c}0,0442 * * * \\
(3,30)\end{array}$ \\
\hline $2000 *$ Keiretsu affiliated & $\begin{array}{c}0,0532 * * * \\
(3,17)\end{array}$ & $\begin{array}{c}0,0524 * * * \\
(3,09)\end{array}$ & $\begin{array}{c}0,0543^{* * *} \\
(3,25)\end{array}$ \\
\hline $2001 *$ Keiretsu affiliated & $\begin{array}{c}0,0658 * * * \\
(4,96)\end{array}$ & $\begin{array}{c}0,0651 * * * \\
(4,90)\end{array}$ & $\begin{array}{c}0,0662 * * * \\
(5,03)\end{array}$ \\
\hline $2002 *$ Keiretsu affiliated & $\begin{array}{c}0,1453^{* * *} \\
(5,95)\end{array}$ & $\begin{array}{c}0,1438 * * * \\
(5,86)\end{array}$ & $\begin{array}{c}0,1456^{* * * *} \\
(5,98)\end{array}$ \\
\hline Industry dummies & Yes & Yes & Yes \\
\hline Year dummies & Yes & Yes & Yes \\
\hline R-squared & 0,375 & 0,373 & 0,375 \\
\hline Observations & 2519 & 2519 & 2519 \\
\hline
\end{tabular}

OLS regressions with White heteroskedasticity-consistent errors. Dependent variable is fees paid to the underwriters as a percentage of proceeds. Principal amount equals total proceeds in millions of US dollars. Sales are reported sales in the year preceding the issue. The same applies to total assets, current ratio, return on assets, and market-to-book. Coupon is the promised annual payment to bondholders as a 
percentage of the bond's face value. Maturity signifies the number of years between the issue date and the promised redemption of the issue. Debt ratio is the ratio of book debt to total assets at the end of year preceding the issue. Standard deviation of EBIT by total assets is over a 5 year period. Lead belongs to same keiretsu as the issuer is a dummy that equals 1 if the issuer and the lead manager of the underwriter syndicate belong to the same keiretsu. Big Four lead is a dummy that equals 1 if the lead manager is one of the Big Four Japanese investment banks (Nomura, Yamaichi, Nikko, or Daiwa). Affiliated is a dummy that equals 1 if the issuer belongs to one of the eight financial keiretsu. Issue in 1995 by affiliated firm is an interaction term of the affiliated dummy and the 1995 year dummy. Year dummies are also independently in the regressions, but are not reported. The same applies to industry dummies. 
Table 6

Separate OLS regressions for affiliated and non-affiliated firms

\begin{tabular}{|c|c|c|c|}
\hline Model & Non-affiliated & Affiliated & Difference \\
\hline Constant & $\begin{array}{c}0,4972 * * * \\
(10,66)\end{array}$ & $\begin{array}{c}0,2328 * * * \\
(7,47)\end{array}$ & $\begin{array}{c}0,2643^{* * *} \\
(-4,71)\end{array}$ \\
\hline Log of principal amount & $\begin{array}{c}-0,0104 * * \\
(-2,03)\end{array}$ & $\begin{array}{c}0,0133^{* * *} \\
(3,50)\end{array}$ & $\begin{array}{c}-0,0237 * * * \\
\quad(-3,71)\end{array}$ \\
\hline Log of sales & $\begin{array}{c}-0,0066^{* * * *} \\
(-4,05)\end{array}$ & $\begin{array}{c}-0,0032 \\
(-1,37)\end{array}$ & $\begin{array}{l}-0,0034 \\
(-1,19)\end{array}$ \\
\hline Coupon & $\begin{array}{c}-0,0014 \\
(-0,18)\end{array}$ & $\begin{array}{c}0,0264 * * * \\
(4,97)\end{array}$ & $\begin{array}{c}-0,0279 * * * \\
\quad(-2,95)\end{array}$ \\
\hline Maturity & $\begin{array}{c}0,0093 * * * \\
(10,69)\end{array}$ & $\begin{array}{c}0,0058^{* * *} \\
(5,20)\end{array}$ & $\begin{array}{c}0,0036 * * \\
(2,53)\end{array}$ \\
\hline Debt ratio & $\begin{array}{c}0,0003 * * \\
(2,02)\end{array}$ & $\begin{array}{l}0,0003 \\
(1,51)\end{array}$ & $\begin{array}{r}0,0000 \\
(0,09)\end{array}$ \\
\hline $\begin{array}{c}\text { Standard deviation of EBIT } \\
\text { by total assets }\end{array}$ & $\begin{array}{c}0,6282^{*} \\
(1,75)\end{array}$ & $\begin{array}{c}0,2058 \\
(1,16)\end{array}$ & $\begin{array}{c}0,4224 \\
(1,06)\end{array}$ \\
\hline $\begin{array}{c}\text { Fixed assets as a percentage } \\
\text { of total assets }\end{array}$ & $\begin{array}{c}-0,0533^{* *} \\
(-2,24)\end{array}$ & $\begin{array}{r}0,0026 \\
(0,20)\end{array}$ & $\begin{array}{c}-0,0559 * * \\
(-2,06)\end{array}$ \\
\hline Current ratio & $\begin{array}{c}-0,0083^{* *} \\
(-2,23)\end{array}$ & $\begin{array}{c}-0,0149 * * * \\
(-2,68)\end{array}$ & $\begin{array}{c}0,0066 \\
(0.99)\end{array}$ \\
\hline Return on assets & $\begin{array}{c}-0,0047 * * \\
(-2,15)\end{array}$ & $\begin{array}{c}-0,0043 \\
(2,46)\end{array}$ & $\begin{array}{c}-0,0090 * * * \\
\quad(-3,22)\end{array}$ \\
\hline Market-to-book & $\begin{array}{c}0,0035^{* *} \\
(2,52)\end{array}$ & $\begin{array}{c}-0,0060 * * * \\
\quad(-2,51)\end{array}$ & $\begin{array}{c}0,0095^{* * *} \\
(3,44)\end{array}$ \\
\hline $\begin{array}{l}\text { Lead belongs to same keiretsu } \\
\text { as the issuer }\end{array}$ & & $\begin{array}{c}-0,0154 * * * \\
\quad(-3,10)\end{array}$ & $\begin{array}{c}0,0154 * * * \\
(-3,10)\end{array}$ \\
\hline Big Four lead & $\begin{array}{c}0,0124 * * * \\
\quad(4,21)\end{array}$ & $\begin{array}{r}-0,0027 \\
(-0,51)\end{array}$ & $\begin{array}{c}0,0151 * * \\
(2,53)\end{array}$ \\
\hline 1995 & $\begin{array}{c}-0,0251^{*} \\
(-1,93)\end{array}$ & $\begin{array}{c}0,0220^{* *} \\
(2,04)\end{array}$ & $\begin{array}{c}-0,0471 * * * \\
\quad(-2,79)\end{array}$ \\
\hline 1996 & $\begin{array}{c}-0,0360 * * * \\
(-2,69)\end{array}$ & $\begin{array}{l}0,017 \\
(1,44)\end{array}$ & $\begin{array}{c}-0,0529 * * * \\
(-2,98)\end{array}$ \\
\hline 1997 & $\begin{array}{c}-0,0303^{*} \\
(-1,69)\end{array}$ & $\begin{array}{c}0,0348^{* * *} \\
(2,64)\end{array}$ & $\begin{array}{c}-0,0651 * * * \\
\quad(-2,93)\end{array}$ \\
\hline 1998 & $\begin{array}{c}-0,0494 * * \\
(-2,48)\end{array}$ & $\begin{array}{c}0,0326 * * \\
(2,40)\end{array}$ & $\begin{array}{c}-0,0820 * * * \\
\quad(-3,40)\end{array}$ \\
\hline 1999 & $\begin{array}{c}-0,0595 * * * \\
(-2,77)\end{array}$ & $\begin{array}{c}0,0609 * * * \\
(3,77)\end{array}$ & $\begin{array}{c}-0,1204 * * * \\
\quad(-4,48)\end{array}$ \\
\hline 2000 & $\begin{array}{c}-0,0513 * \\
(-1,83)\end{array}$ & $\begin{array}{c}0,0793 * * * \\
(4,42)\end{array}$ & $\begin{array}{c}-0,1306 * * * \\
\quad(-3,93)\end{array}$ \\
\hline 2001 & $\begin{array}{c}-0,0745^{* * *} \\
(-2,80)\end{array}$ & $\begin{array}{c}0,0960^{* * *} \\
(5,27)\end{array}$ & $\begin{array}{c}-0,1705 * * * \\
\quad(-5,29)\end{array}$ \\
\hline 2002 & $\begin{array}{c}-0,0735 * * * \\
(-2,79)\end{array}$ & $\begin{array}{c}0,1587 * * * \\
(5,47)\end{array}$ & $\begin{array}{c}-0,2323 * * * \\
(-5,92)\end{array}$ \\
\hline Industry dummies & Yes & Yes & \\
\hline $\begin{array}{l}\text { R-squared } \\
\text { Observations }\end{array}$ & $\begin{array}{r}0,463 \\
1246\end{array}$ & $\begin{array}{l}0,427 \\
1273\end{array}$ & \\
\hline
\end{tabular}

OLS regressions with White heteroskedasticity-consistent errors. Dependent variable is fees paid to the underwriters as a percentage of proceeds. Principal amount equals total proceeds in millions of US dollars. Sales are reported sales in the year preceding the issue. The same applies to current ratio, return on assets, and market-to-book. Coupon is the promised annual payment to bondholders as a percentage of the bond's face value. Maturity signifies the number of years between the issue date and the promised redemption of the issue. Debt ratio is the ratio of book debt to total assets at the end of year preceding the issue. Standard deviation of EBIT by total assets is over a 5 year period. Lead belongs to same keiretsu as the issuer is a dummy that equals 1 if the issuer and the lead manager of the underwriter syndicate belong to the same keiretsu. Big Four lead is a dummy that equals 1 if the lead manager is one of the Big Four Japanese investment banks (Nomura, 
Yamaichi, Nikko, or Daiwa). 1995, 1996, etc. are year dummies that equal 1 if the issue is done in that particular year. Industry dummies are independently in the regressions, but are not reported. 


\section{Publications in the Report Series Research* in Management}

\section{ERIM Research Program: "Finance and Accounting"}

2005

Royal Ahold: A Failure Of Corporate Governance

Abe De Jong, Douglas V. Dejong, Gerard Mertens en Peter Roosenboom ERS-2005-002-F\&A

http://hdl.handle.net/1765/1863

Capital Structure Policies in Europe: Survey Evidence

Dirk Brounen, Abe de Jong and Kees Koedijk

ERS-2005-005-F\&A

$\underline{\text { http://hdl.handle.net/1765/1923 }}$

A Comparison of Single Factor Markov-Functional and Multi Factor Market Models

Raoul Pietersz, Antoon A. J. Pelsser

ERS-2005-008-F\&A

http://hdl.handle.net/1765/1930

Efficient Rank Reduction of Correlation Matrices

Igor Grubišić and Raoul Pietersz

ERS-2005-009-F\&A

http://hdl.handle.net/1765/1933

Generic Market Models

Raoul Pietersz and Marcel van Regenmortel

ERS-2005-010-F\&A

http://hdl.handle.net/1765/1907

The price of power: valuing the controlling position of owner-managers in french ipo firms

Peter Roosenboom and Willem Schramade

ERS-2005-011-F\&A

http://hdl.handle.net/1765/1921

The Success of Stock Selection Strategies in Emerging Markets: Is it Risk or Behavioral Bias?

Jaap van der Hart, Gerben de Zwart and Dick van Dijk

ERS-2005-012-F\&A

http://hdl.handle.net/1765/1922

Sustainable Rangeland Management Using a Multi-Fuzzy Model: How to Deal with Heterogeneous Experts' Knowledge Hossein Azadi, Mansour Shahvali, Jan van den Berg and Nezamodin Faghih

ERS-2005-016-F\&A

http://hdl.handle.net/1765/1934

A Test for Mean-Variance Efficiency of a given Portfolio under Restrictions

Thierry Post

ERS-2005-016-F\&A

Testing for Stochastic Dominance Efficiency

Oliver Linton, Thierry Post and Yoon-Jae Whang

ERS-2005-033-F\&A

Wanted: A Test for FSD Optimality of a Given Portfolio

Thierry Post

ERS-2005-034-F\&A 
How Domestic is the Fama and French Three-Factor Model? An Application to the Euro Area

Gerard A. Moerman

ERS-2005-035-F\&A

http://hdl.handle.net/1765/6626

Bond underwriting fees and keiretsu affiliation in Japan

Abe de Jong, Peter Roosenboom and Willem Schramade

ERS-2005-038-F\&A

* A complete overview of the ERIM Report Series Research in Management: https://ep.eur.nl/handle/1765/1

ERIM Research Programs:

LIS Business Processes, Logistics and Information Systems

ORG Organizing for Performance

MKT Marketing

F\&A Finance and Accounting

STR Strategy and Entrepreneurship 